\title{
Impact of the Desert dust on the summer monsoon system over Southwestern North America
}

\author{
C. Zhao, X. Liu, and L. R. Leung \\ Atmospheric Sciences and Global Change Division, Pacific Northwest National Laboratory, Richland, WA, USA \\ Correspondence to: C. Zhao (chun.zhao@pnnl.gov)
}

Received: 20 October 2011 - Published in Atmos. Chem. Phys. Discuss.: 2 December 2011

Revised: 4 April 2012 - Accepted: 9 April 2012 - Published: 24 April 2012

\begin{abstract}
The radiative forcing of dust emitted from the Southwest United States (US) deserts and its impact on monsoon circulation and precipitation over the North America monsoon (NAM) region are simulated using a coupled meteorology and aerosol/chemistry model (WRF-Chem) for 15 years (1995-2009). During the monsoon season, dust has a cooling effect $\left(-0.90 \mathrm{~W} \mathrm{~m}^{-2}\right)$ at the surface, a warming effect $\left(0.40 \mathrm{~W} \mathrm{~m}^{-2}\right)$ in the atmosphere, and a negative topof-the-atmosphere (TOA) forcing $\left(-0.50 \mathrm{~W} \mathrm{~m}^{-2}\right)$ over the deserts on 24-h average. Most of the dust emitted from the deserts concentrates below $800 \mathrm{hPa}$ and accumulates over the western slope of the Rocky Mountains and Mexican Plateau. The absorption of shortwave radiation by dust heats the lower atmosphere by up to $0.5 \mathrm{~K} \mathrm{day}^{-1}$ over the western slope of the Mountains. Model sensitivity simulations with and without dust for 15 summers (June-July-August) show that dust heating of the lower atmosphere over the deserts strengthens the low-level southerly moisture fluxes on both sides of the Sierra Madre Occidental. It also results in an eastward migration of NAM-driven moisture convergence over the western slope of the Mountains. These monsoonal circulation changes lead to a statistically significant increase of precipitation by up to $\sim 40 \%$ over the eastern slope of the Mountains (Arizona-New Mexico-Texas regions). This study highlights the interaction between dust and the NAM system and motivates further investigation of possible dust feedback on monsoon precipitation under climate change and the megadrought conditions projected for the future.
\end{abstract}

\section{Introduction}

The North American Monsoon (NAM) system is a major climate system that significantly affects the regional hydrological cycle over large areas of the southwestern United States (US) and northwestern Mexico. The NAM system is characterized by a combination of seasonally warm land surfaces and atmospheric moisture from nearby maritime sources that together produce convection that contributes over $70 \%$ of annual precipitation to the region. The NAM summer rainfall typically begins in July with a pronounced increase from an extremely dry condition and lasts until September when the dry regime reestablishes (Adams and Comrie, 1997). The deserts over the Southwest US cover an arid expanse of $\sim 190000$ square miles and are bordered by the Sierra Nevada Range on the west and the Rocky Mountains on the east, and the Columbia Plateau to the north. The deserts are north of the NAM region.

The Southwest US deserts are the main sources of dust aerosol over the southwestern US. Dust aerosol has important climate impact through changes in solar and terrestrial radiation and radiative and microphysical properties of clouds (e.g., Sokolik et al., 1998; Ginoux et al., 2001; Lau et al., 2009; Zhao et al., 2011). The dust lofted from the deserts near the monsoon regions may affect monsoon circulation and precipitation worldwide. Recent years, many efforts have begun to study dust impacts on the West African Monsoon (WAM) and the Asian Monsoon (AM) circulation and precipitation, using general circulation models (GCMs) and regional models combined with observations (e.g., Miller et al., 2004; Yoshioka et al., 2007; Lau et al., 2006, 2009; Kim et al., 2010; Zhao et al., 2011). These studies have provided important understanding of the 
fundamental processes associated with dust effect on the two monsoon systems. Over West Africa, Lau et al. (2009) and Kim et al. (2010) showed that the Saharan dust radiative effect could strengthen the WAM, which is manifested in a northward shift of the West African precipitation over land. Kim et al. (2010) and Zhao et al. (2011) also found that dust could affect not only the total amount but also diurnal cycle of WAM precipitation simulated by a GCM and a regional model, respectively. Over Asia, Lau et al. (2006) elucidated a plausible "heat-pump" mechanism for dust impact on the Asian summer monsoon using the NASA finitevolume GCM. As dust from the deserts of western China, Pakistan, and the Middle East are transported into and accumulate against the northern and southern slopes of the Tibet Plateau, the dust heated air over the slopes can draw in warm and moist air over the Indian subcontinent, suggesting that the dust loading may lead to an advance of the rainy periods and subsequently an intensification of the Indian summer monsoon.

The dust emitted from the Southwest US deserts is less than that emitted from the Saharan desert and the Asian deserts; however the NAM system is also weaker than the monsoon systems over West Africa and Asia. Therefore, dust could still have significant effect on the NAM system. The IPCC AR4 climate model simulations projected warmer and dryer conditions for the southwestern US and northwestern Mexico in the 21st century. The projected drought parallels the severity of the 1930s Dust Bowl (Seager et al., 2007). The mega-droughts may lead to widespread dust storms (e.g., Woodhouse and Overpeck, 1998) that interact with the NAM system, strengthening or weakening the monsoon system through positive or negative feedbacks. To the best of our knowledge, the potential dust impact on NAM is not fully understood.

To improve understanding of dust impact on NAM in current and future climate conditions, as the first step, we used the regional model WRF-Chem to investigate the dust impact on the NAM system in the current climate condition. The objective of this study is to investigate the radiative forcing of dust from the Southwest US deserts and how it affects the NAM circulation and precipitation at a regional scale. This study (1) examines both SW and LW radiative forcings of dust during the NAM season over the Southwest US, and (2) investigates the potential dust effects on circulation and precipitation during the NAM season. Dust effects on cloud and precipitation through aerosol indirect effects are not considered in this study as the primary dust source region is generally removed from the monsoon core region where clouds are prominent (Sect. 4.1). The paper is organized as follows. Sections 2 and 3 detail the WRF-Chem model and the measurements used in this study. The SW and LW radiative forcings of the dust and their impact on the NAM circulation and precipitation are analyzed in Sect. 4 . The paper concludes in Sect. 5.

\section{Model description}

WRF-Chem, a version of WRF (Skamarock et al., 2008), simulates trace gases and particulates simultaneously with the meteorological fields (Grell et al., 2005). Grell et al. (2005) implemented the RADM2 (Regional Acid Deposition Model 2) photochemical mechanism (Stockwell et al., 1990) and the MADE/SORGAM (Modal Aerosol Dynamics Model for Europe (MADE) and Secondary Organic Aerosol Model (SORGAM)) aerosol model (Ackermann et al., 1998; Schell et al., 2001) into WRF-Chem. MADE/SORGAM in WRF-Chem uses the modal approach with three modes (Aitken, accumulation, and coarse modes, assuming a log-normal distribution within each mode) to represent the aerosol size distribution. Different aerosol species within each size mode are assumed to be internally mixed so that all particles within a size mode have the same chemical composition. In MADE/SORGAM, aerosol species include sulfate, nitrate, ammonium, black carbon (BC), organic matters $(\mathrm{OM})$, sea salt, mineral dust, and water. Aerosol optical properties for scattering (e.g., single-scattering albedo, asymmetry factor, and extinction) are computed as a function of wavelength and three-dimensional position. A complex refraction index is calculated by volume averaging for each mode for each chemical constituent of the aerosol. To efficiently compute the extinction efficiency $\left(\mathrm{Q}_{\mathrm{e}}\right)$ and the scattering efficiency $\left(\mathrm{Q}_{\mathrm{s}}\right)$, WRF-Chem follows a methodology described by Ghan et al. (2001) that performs the full Mie calculations once first to obtain a table of seven sets of Chebyshev expansion coefficients, and later the full Mie calculations are skipped and $\mathrm{Q}_{\mathrm{e}}$ and $\mathrm{Q}_{\mathrm{s}}$ are calculated using bilinear interpolation over the Chebyshev coefficients stored in the table. A detailed description of the computation of aerosol optical properties in WRF-Chem can be found in Fast et al. (2006) and Barnard et al. (2010).

The GOCART dust emission scheme (Ginoux et al., 2001) was first coupled with MADE/SORGAM in WRF-Chem by Zhao et al. (2010) to investigate the sensitivities in simulating the size distributions and optical properties of Saharan dust to emitted dust size distributions and aerosol size treatments during the dry season (from January to February) of 2006 over West Africa and understand the various radiative forcings of Saharan dust and how they jointly affect the hydrological cycle at a regional scale (Zhao et al., 2011). As described in Ginoux et al. (2001), the GOCART scheme calculates the dust emission flux $G$ as

$G=C S_{p} u_{10 \mathrm{~m}}^{2}\left(u_{10 \mathrm{~m}}-u_{\mathrm{t}}\right)$

where $C$ is an empirical proportionality constant, $S$ is a source function which defines the potential dust source regions and comprises surface factors, such as vegetation and snow cover, $s_{p}$ is a fraction of each size class of dust in emission, $u_{10 \mathrm{~m}}$ is the horizontal wind speed at $10 \mathrm{~m}, u_{\mathrm{t}}$ is the threshold wind velocity below which dust emission does not 

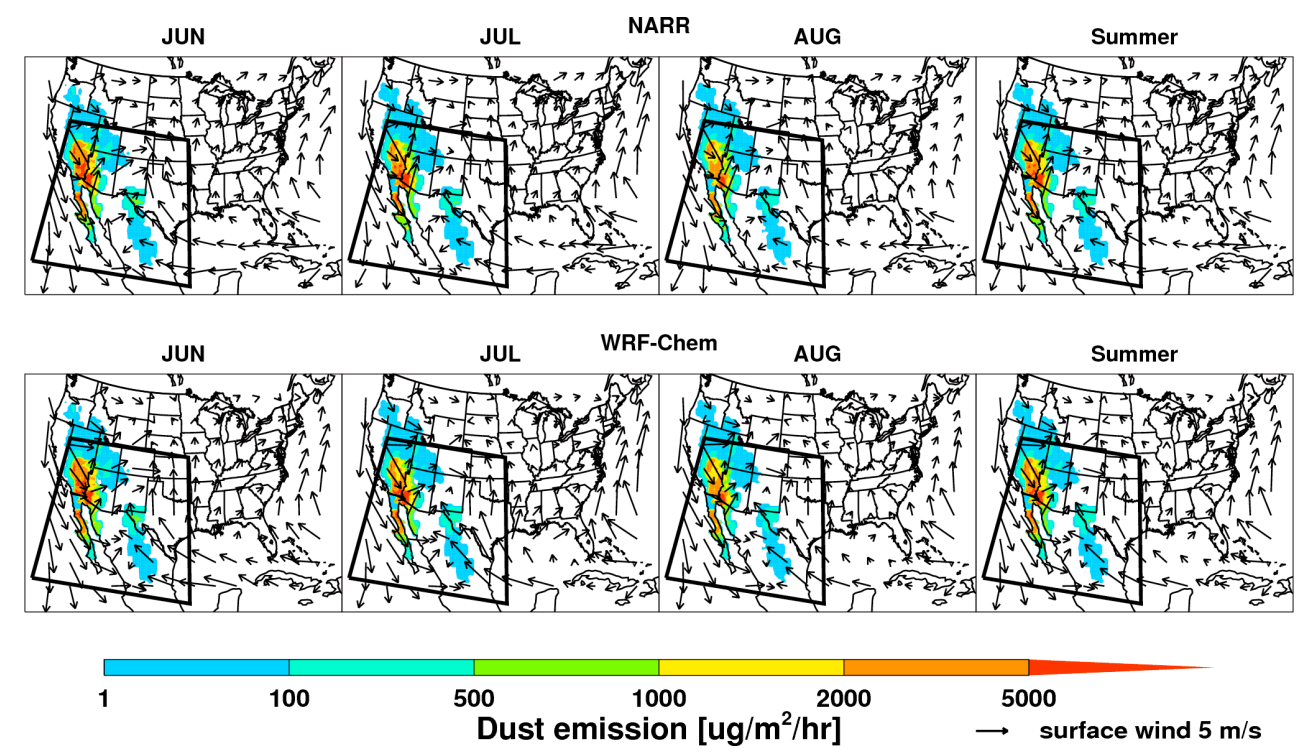

Fig. 1. Spatial distributions of 10-m wind from NARR reanalysis data and WRF-Chem simulations and dust emissions from WRF-Chem simulations in June, July, August, and summer averaged for 1995-2009. The region in black box is defined as the North America Monsoon (NAM) region $\left(20^{\circ} \mathrm{N}-40^{\circ} \mathrm{N}, 120^{\circ} \mathrm{W}-95^{\circ} \mathrm{W}\right)$.

occur and is a function of particle size, air density, and surface soil moisture. The size distribution of emitted dust is assumed to follow log-normal distribution corresponding to the MADE/SOGAM aerosol model (Zhao et al., 2010). More details about the coupling of GOCART dust emission scheme with WRF-Chem can be found in Zhao et al. (2010).

In this study, the WRF-Chem (v3.2.1) domain covers the entire US and northern Mexico $\left(133.05^{\circ} \mathrm{W}-58.95^{\circ} \mathrm{W}\right.$, $\left.15.95^{\circ} \mathrm{N}-51.53^{\circ} \mathrm{N}\right)($ Fig. 1) using $150 \times 100$ grid points at $36 \mathrm{~km}$ horizontal resolution and 35 vertical layers with model top pressure at $100 \mathrm{hPa}$. To investigate the NAM feature, the analysis is mainly shown over the NAM region that is defined as $\left(20^{\circ} \mathrm{N}-40^{\circ} \mathrm{N}, 120^{\circ} \mathrm{W}-95^{\circ} \mathrm{W}\right)$ following previous studies (Gutzler, 2004 and 2009) (Black box in Fig. 1). Two sets of 15-yr simulations are conducted from 10 April to 31 August for 1995-2009 with and without dust. The simulation of each year runs continuously for 10 April-31 August. Only the results from 1 June to 31 August each year (referred as the NAM season hereafter) are used in the analysis to minimize the impact from the chemical and land surface initial conditions. The model configuration for dust simulation follows Zhao et al. (2010 and 2011). The refractive index of dust is set to $1.53+0.003 \mathrm{i}$ as Zhao et al. (2010 and 2011) over West Africa because of insufficient information to constrain the values over the Southwest US. The rapid radiative transfer model (RRTMG) (Mlawer et al., 1997; Iacono et al., 2000) for both SW and LW radiation is used to simulate aerosol direct radiative effect as Zhao et al. (2011). The Morrison scheme and Grell scheme are used to represent cloud microphysics and convection processes. Although aerosol activation to cloud droplet (Cloud Condensation $\mathrm{Nu}-$ clei (CCN) effect) is included in the cloud microphysical parameterization of stratiform (large-scale) clouds to account for cloud chemistry and aerosol wet deposition (Gustafson et al., 2007), dust 1st and 2nd indirect effects on the NAM system are not investigated in this study because the simulated dust coincides minimally with the NAM precipitation region. In addition, dust effect by acting as ice nuclei (IN) is not treated in the current version of WRF-Chem. The Noah land surface model and Mellor-Yamada-Janjic (MYJ) planetary boundary scheme are used.

Large-scale meteorological fields are assimilated with lateral boundary and initial conditions from the North American Regional Reanalysis (NARR) data, which also provide the prescribed sea surface temperature (SST) for the simulations. Chemical lateral boundary conditions are from the default profiles in WRF-Chem, which are based on the averages of mid-latitude aircraft profiles from several field studies over the eastern Pacific Ocean (McKeen et al., 2002). Anthropogenic emissions are obtained from the US National Emission Inventory (NEI) 2005 (WRF-Chem user guide from http://ruc.noaa.gov/wrf/WG11/Users_guide.pdf). Biomass burning emissions are obtained from the Global Fire Emissions Database, Version 3 (GFEDv3) with monthly temporal resolution (van der Werf et al., 2010).

\section{Observations}

\subsection{AERONET surface observation network}

The Aerosol Robotic Network (AERONET) (Holben et al., 1998) has $\sim 100$ identical globally distributed sun- and 

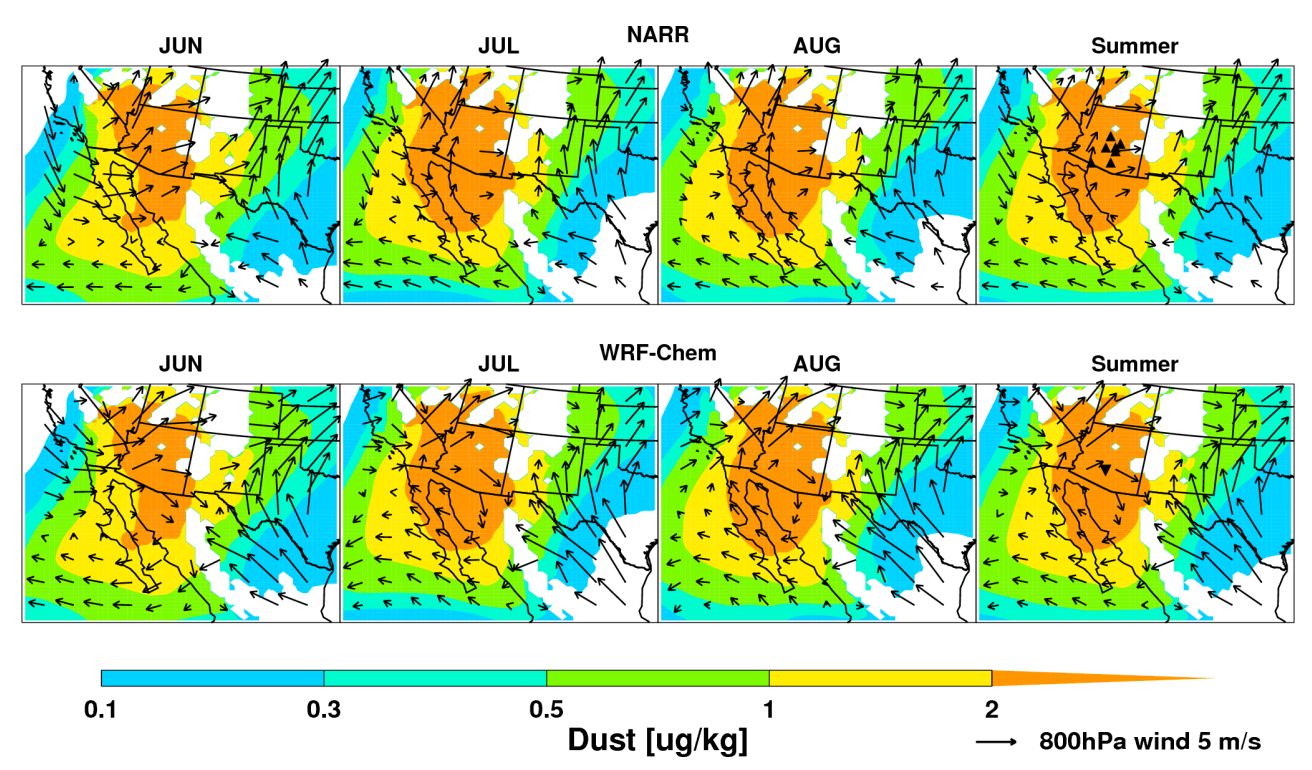

Fig. 2. Spatial distributions of wind over the NAM region from NARR reanalysis data and WRF-Chem simulations and dust concentrations from WRF-Chem simulations at $800 \mathrm{hPa}$ in June, July, August, and summer averaged for 1995-2009. The seven upward black triangles (rightmost of the top panel) represent the IMPROVE sites; the one downward black triangle (rightmost of the bottom panel) represents the AERONET site Maricopa in Arizona.

sky-scanning ground-based automated radiometers, which provide measurements of aerosol optical properties throughout the world (Dubovik and King, 2000; Dubovik et al., 2002). In this study, AERONET measured aerosol optical depth (AOD) at $675 \mathrm{~nm}$ and $440 \mathrm{~nm}$ from one Arizona site (Maricopa, $111.97^{\circ} \mathrm{W}, 33.07^{\circ} \mathrm{N}$, Fig. 2) near the dust source region are used to derive the AOD at $550 \mathrm{~nm}$ (using the Angström exponent) for comparison with model results. All of the retrievals of AOD are quality level 2, and the uncertainty of AOD measurements is about \pm 0.01 (Holben et al., 2001). In this study, the available data from 2003 to 2009 are used to evaluate the modeling results during the same period.

\subsection{MODIS}

The Moderate Resolution Imaging Spectroradiometer (MODIS) instruments with wide spectral range, high spatial resolution, and near daily global coverage are designed on board the NASA Aqua platforms to observe and monitor the Earth changes including tropospheric aerosols (Kaufman et al., 1997). The standard MODIS aerosol product does not retrieve aerosol information over bright surfaces (e.g., desert) due to a strong surface spectral contribution in the visible range (Kaufman et al., 1997). However, a new algorithm, called the "Deep Blue algorithm" (Hsu et al., 2006), has been integrated with the existing MODIS algorithm to retrieve AOD even over bright surfaces. Therefore, the retrieved "deep blue" AOD from MODIS (Collection 5.1) (only available over land so far) (Levy et al., 2007; Remer et al., 2005) is used in this study. The MODIS on board the Aqua platform passes over the equator at $\sim 13: 30 \mathrm{LT}$ during daytime (Kaufman et al., 1997). In this study, the available data from 2003 to 2009 are used to evaluate the modeling results during the same period. Model results are sampled in the same overpass time as Aqua when comparing with MODIS retrievals.

\subsection{MISR}

Since February 2000, the Multi-angle Imaging SpectroRadiometer (MISR) instrument on board the NASA Terra platform observes AOD continuously at nine distinct zenith angles, ranging from $70^{\circ}$ afterward to $70^{\circ}$ forward, and in four narrow spectral bands centered at 446, 558, 672, and $866 \mathrm{~nm}$. MISR's unique blend of directional and spectral data allows aerosol retrieval algorithms to be used that do not depend on the explicit radiometric surface properties. Therefore, MISR can retrieve aerosol properties even over highly reflective surfaces (e.g., deserts) (Diner et al., 1998; Martonchik et al., 2004). The MISR on board the Terra platform passes over the equator at $\sim 10: 45$ LT during daytime (Diner et al., 2001). In this study, the available data from 2003 to 2009 are used to evaluate the modeling results during the same period. Model results are sampled in the same overpass time as Terra when comparing with MISR retrievals.

\subsection{IMPROVE}

The Interagency Monitoring for Protected Visual Environments (IMPROVE) program was started in 1985 by the US federal agencies EPA, National Park Services, Department of Agriculture-Forest Service, and other land management 


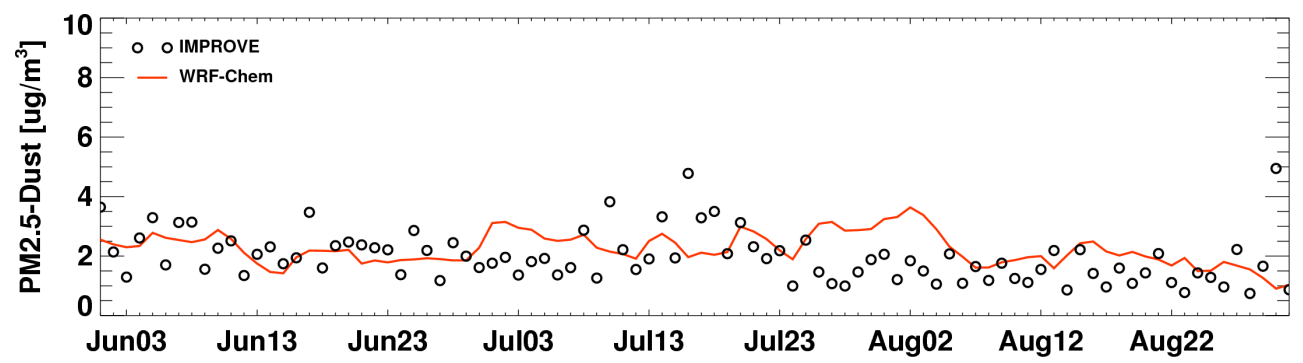

Fig. 3. Daily fine dust (with diameter $<2.5 \mu \mathrm{m}$ ) mass concentrations averaged for the seven IMPROVE sites (Fig. 2) over the southwestern US from the IMPROVE measurements and WRF-Chem simulations for June-August 1995-2009.

agencies as a part of the EPA Regional Haze program (Malm et al., 1994). There are more than 100 IMPROVE sites in the US regularly measuring aerosol chemical compositions as well as fine and coarse mode aerosol mass concentrations (http://vista.cira.colostate.edu/IMPROVE). The mass of dust is estimated from the measured elements associated predominantly with soil, including $\mathrm{Ti}, \mathrm{Al}, \mathrm{Si}, \mathrm{Ca}$, and $\mathrm{Fe}$. The uncertainties of estimated values results from the range and variation of mineral composition from a variety of soil types (see Malm et al., 1994 for details). Since there is no IMPROVE sites over the deserts, fine dust (with diameter less than $2.5 \mu \mathrm{m}$ ) mass concentrations from the 7 sites in the region $\left(110^{\circ} \mathrm{W}-112^{\circ} \mathrm{W}, 31^{\circ} \mathrm{N}-35^{\circ} \mathrm{N}\right.$, mostly located in Arizona, Fig. 2) near the deserts during 1995-2009 are used to evaluate model results.

\subsection{TRMM}

The 3B-43 product of the Tropical Rainfall Measuring Mission (TRMM) data is used. The purpose of algorithm 3B-43 is to produce TRMM merged high quality (HQ)/infrared (IR) precipitation and root-mean-square (RMS) precipitationerror estimates. These gridded estimates are on a monthly temporal resolution and a $0.25 \times 0.25$ degree spatial resolution in a global belt extending from $50^{\circ} \mathrm{S}$ to $50^{\circ} \mathrm{N}$ latitude. Detailed description of the dataset can be found in Huffman et al. (2001 and 2007). In this study, the available data from 2000 to 2009 are used to evaluate the modeling results during the same period.

\subsection{PERSIANN}

Precipitation Estimation from Remote Sensing Information using Artificial Neural Network (PERSIANN) provides hourly precipitation data on a $0.25 \times 0.25$ degree spatial resolution in a global belt extending from $60^{\circ} \mathrm{S}$ to $60^{\circ} \mathrm{N}$ latitude (Hsu et al., 1999; Sorooshian et al., 2000). In the PERSIANN system, a neural network trained by precipitation from the TRMM Microwave Imager (TMI) and other microwave measurements (Hsu et al., 1997 and 1999) was used to estimate 30-min precipitation rates from infrared (IR) and visible imagery from geostationary satellites. In this study, the avail- able data from 2000 to 2009 are used to evaluate the modeling results during the same period.

\section{Results and discussion}

\subsection{Modeling dust and its radiative forcing}

Figure 1 shows the monthly mean spatial distribution of 10$\mathrm{m}$ wind circulation from NARR reanalysis data and WRFChem simulations in June, July, August, and summer averaged for 1995-2009. The dust emissions from WRF-Chem simulations are also shown. The model well captures the surface wind circulation compared to the NARR reanalysis data. Dust emission occurs mostly over the southwestern US. The monthly variation of dust emission is small during summer. WRF-Chem simulates a total dust emission of $2.4 \mathrm{Tg}$ for the summer season. Figure 2 shows the monthly mean spatial distribution of wind circulation at $800 \mathrm{hPa}$ from NARR reanalysis data and WRF-Chem simulations in June, July, August, and summer averaged for 1995-2009 over the NAM region. The dust mass concentration at $800 \mathrm{hPa}$ from WRFChem simulations is also shown. Overall, the model simulated wind circulation is consistent with the reanalysis data, although the model tends to simulate weaker southerly flows in Arizona from the Gulf of California compared to the reanalysis data. However, Mo and Berbery (2004) found that the NARR reanalysis overestimates the Gulf of California low-level jets during the NAM season. In general, dust concentrates near the deserts in all months. The model simulates higher dust concentration over the source region in July and August than that in June. The dust in June stretches further east than that in July and August.

The model simulated surface mass concentration of fine dust (with diameter $<2.5 \mu \mathrm{m}$ ) is compared to the IMPROVE data at the sites near the dust source region (Fig. 3). The daily variation of dust concentration at the sites from both model simulations and IMPROVE data is small. The 15-yr summer average of dust concentrations at all sites from model simulations is $2.2 \mu \mathrm{g} \mathrm{m}^{-3}$, well consistent with the IMPROVE data of $2.0 \mathrm{\mu g} \mathrm{m}^{-3}$. The simulated AOD near the dust source region is also evaluated with the AERONET, MODIS, 


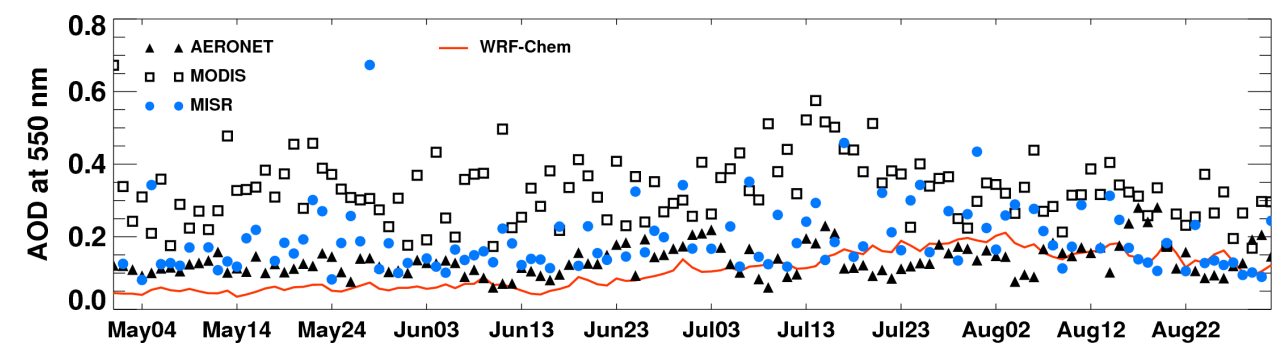

Fig. 4. Daily AOD from the measurements of AERONET, MODIS, and MISR and simulations by WRF-Chem at the AERONET site Maricopa (Fig. 2) for May-August, 2003-2009.

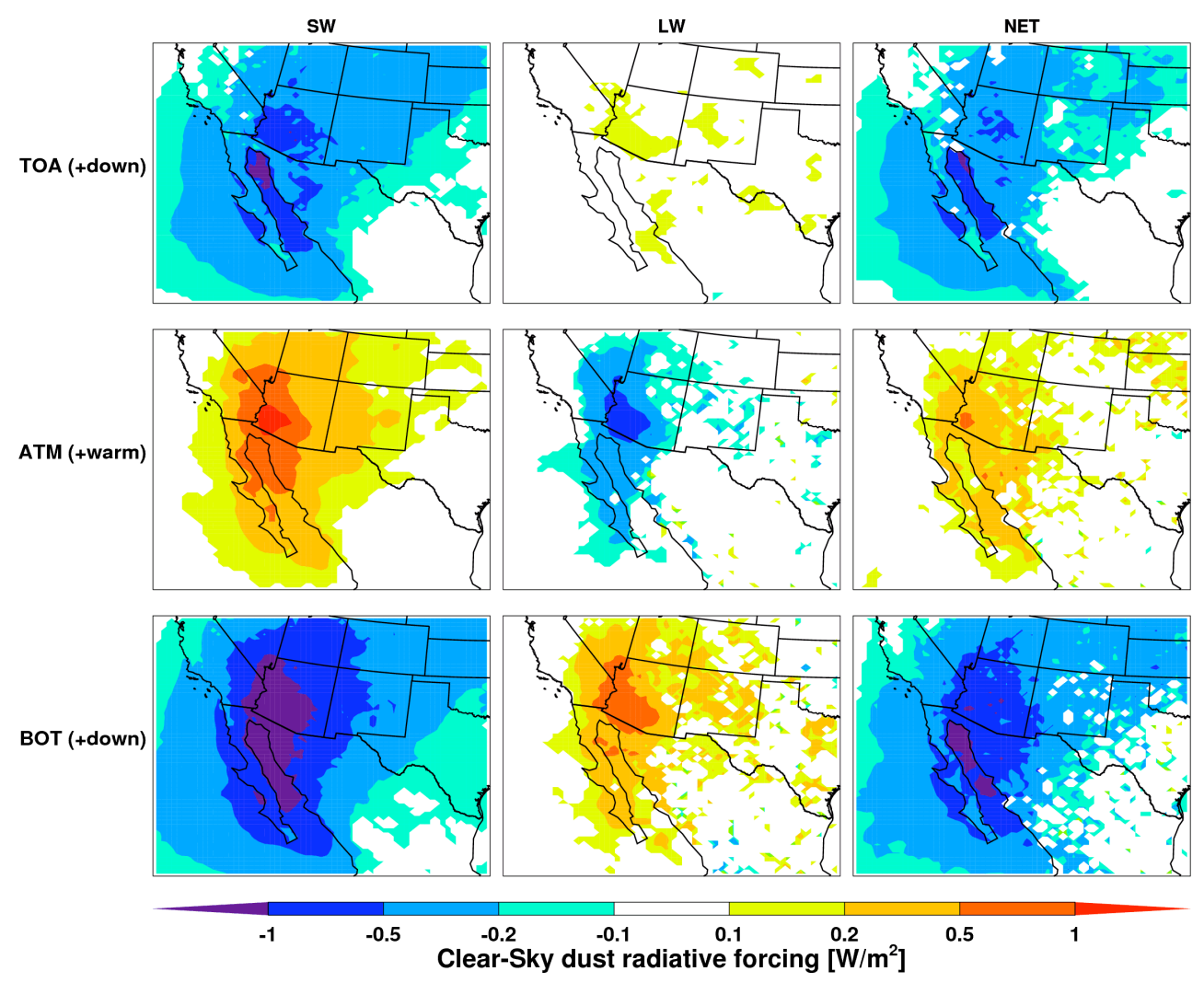

Fig. 5. Averaged clear-sky SW and LW radiative forcing of dust over the NAM region from WRF-Chem simulations. "TOA (+down)" represents the dust radiative forcing at the top of atmosphere and positive refers to downward direction; "ATM (+warm)" represents the dust radiative forcing in the atmosphere and positive refers to warming effect; "BOT (+down)" represents the dust radiative forcing at the surface and positive refers to downward direction. "Net" represents the sum of dust SW and LW radiative forcing.

and MISR measurements at the AERONET site Maricopa (Fig. 4). In general, the model captures the AERONET measured AOD, although the simulated AOD has smaller variation compared to the AERONET measurements, which may be due to uncertainties of local emission sources during the simulations. The model simulates climatological summermean AOD of 0.11 at site Maricopa, which is comparable to the AERONET measured value of 0.13 and the MISR retrieved value of 0.18 . MODIS retrieved a much higher value of 0.33. Compared to the AOD value of 0.07 from the sen- sitivity model simulations without dust emissions, the dust contributes $\sim 45 \%$ of AOD at the site Maricopa.

Figure 5 shows the WRF-Chem simulated 24-h averaged spatial distribution of clear-sky dust SW, LW, and net $(\mathrm{SW}+\mathrm{LW})$ radiative forcing at the top and bottom of the atmosphere and in the atmosphere during the summer period over the NAM region. The dust radiative forcing is derived from the WRF-Chem simulations with and without dust. At the top of atmosphere (TOA), the dust SW radiative forcing is negative throughout the domain. The pattern is consistent with the spatial distribution of dust mass concentration 

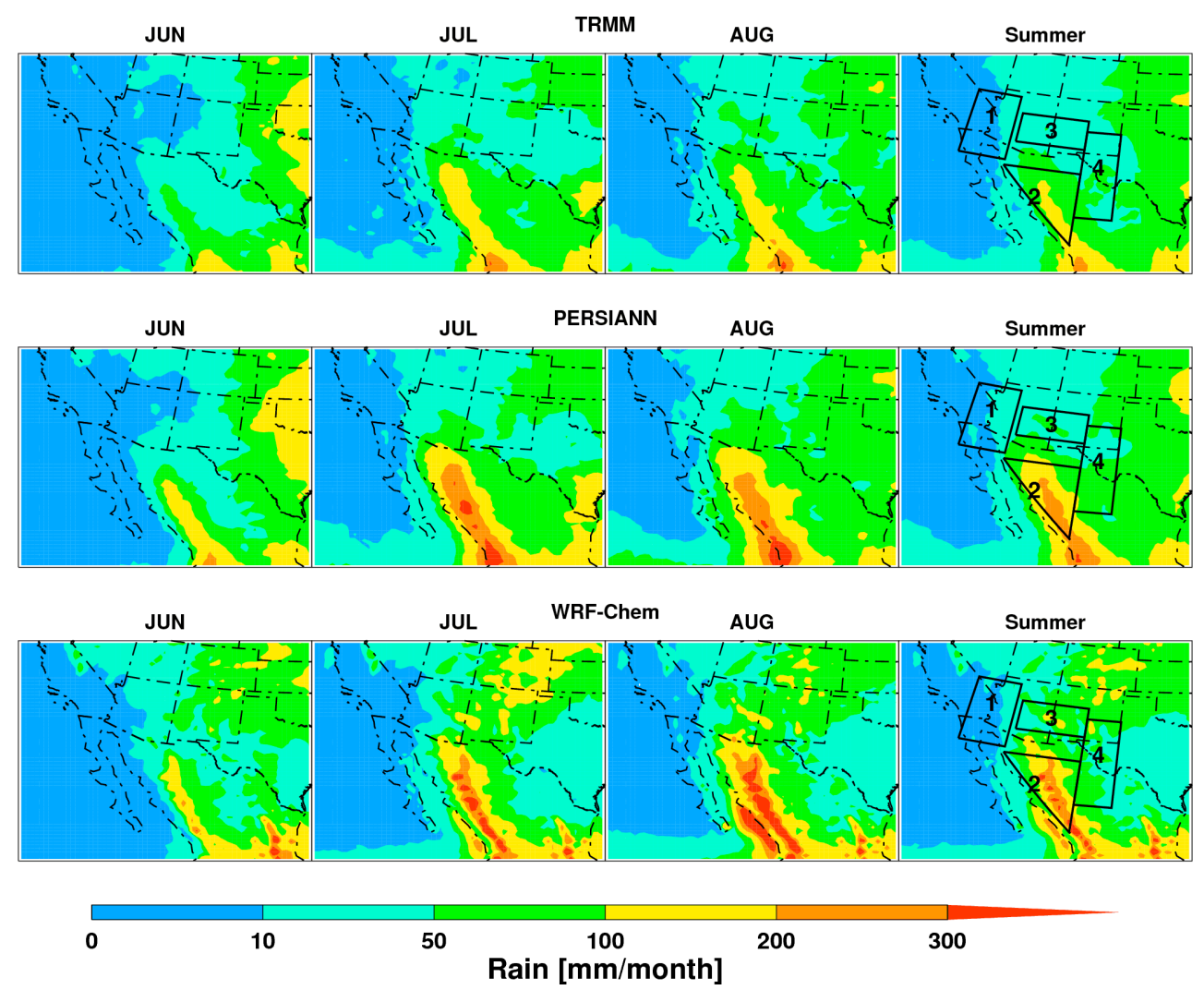

Fig. 6. Spatial distributions of precipitation over the NAM region from TRMM and PERSIANN data and WRF-Chem simulations in June, July, August, and summer averaged for 2000-2009. Four sub-regions are defined in the black boxes (rightmost column): Region 1 (DESERT), Region 2 (CORE), Region 3 (AZNM), and Region 4 (TXNM).

(Fig. 2) with the highest forcing of $-1.25 \mathrm{~W} \mathrm{~m}^{-2}$ over the desert region. The dust LW radiative forcing at TOA is mostly close to zero with some slightly positive values over the domain. Overall, the simulated dust net $(\mathrm{SW}+\mathrm{LW})$ radiative forcing at TOA has a cooling effect of $-0.1 \mathrm{~W} \mathrm{~m}^{-2}$ on domain average with a maximum of $-1.15 \mathrm{~W} \mathrm{~m}^{-2}$ over the deserts. In the atmosphere, dust absorbs SW and warms the atmosphere. Dust LW effect cools the atmosphere. The dust LW forcing is higher over the desert because of the hotter desert surface and stronger interaction between LW and coarse mode dust particles that are spatially confined to the desert due to their shorter lifetimes and distance being carried. In the atmosphere, dust produces a net $(\mathrm{LW}+\mathrm{SW})$ warming effect with a domain average of $0.05 \mathrm{~W} \mathrm{~m}^{-2}$ and a maximum of $0.6 \mathrm{~W} \mathrm{~m}^{-2}$. At the surface, dust has a cooling effect (domain average of $-0.2 \mathrm{~W} \mathrm{~m}^{-2}$ and maximum of $-2.1 \mathrm{~W} \mathrm{~m}^{-2}$ ) by reducing the downward SW radiation and a warming effect (domain average of $0.05 \mathrm{~W} \mathrm{~m}^{-2}$ and maximum of $0.98 \mathrm{~W} \mathrm{~m}^{-2}$ ) by trapping the LW radiation emitted from surface. The net $(\mathrm{LW}+\mathrm{SW})$ dust radiative forcing at the surface is $-0.15 \mathrm{~W} \mathrm{~m}^{-2}$ on domain average and $-1.38 \mathrm{~W} \mathrm{~m}^{-2}$ on maximum. Over the deserts, the dust has a cooling effect $\left(-0.90 \mathrm{~W} \mathrm{~m}^{-2}\right)$ at the surface, a warming effect $\left(0.40 \mathrm{~W} \mathrm{~m}^{-2}\right)$ in the atmosphere, and a negative TOA forcing $\left(-0.50 \mathrm{~W} \mathrm{~m}^{-2}\right)$.

\subsection{Radiative impact of dust on NAM precipitation and circulation}

\subsubsection{NAM precipitation and circulation}

Figure 6 shows the monthly and seasonal mean spatial distribution of precipitation from TRMM and PERSIANN observations and WRF-Chem simulations over the NAM region. Both TRMM and PERSIANN show a typical monthly monsoonal evolution. Monsoon onset occurs in June in most of western Mexico south of $\sim 30^{\circ} \mathrm{N}$ and reaches the international border and then the southwestern US in July and $\mathrm{Au}$ gust. Rainfall intensifies strongly and rapidly in July, with maximum rainfall rates along the western foothills of the Sierra Madre Occidental (SMO) in northwestern Mexico, consistent with previous studies (e.g., Gutzler, 2009). Although, TRMM observes the spatial variability of the NAM precipitation, it underestimates the NAM precipitation compared to the PERSIANN data. It has been found that satellite retrievals have low biases for NAM precipitation (Nesbitt et al., 2008; Gochis et al., 2009; Gutzler, 2009). The model 


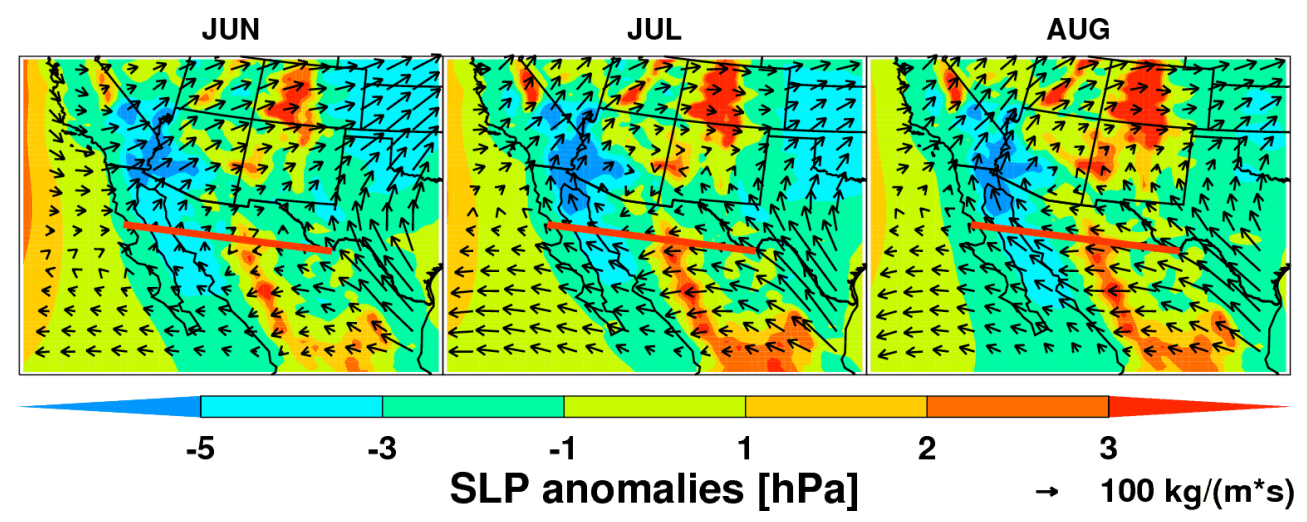

Fig. 7. Spatial distributions of monthly mean sea level pressure (SLP) anomalies and integrated moisture fluxes from the WRF-Chem simulations in June, July, and August averaged for 1995-2009 over the NAM region. The red line represents the cross section at $29^{\circ} \mathrm{N}$ from $115^{\circ} \mathrm{W}$ to $105^{\circ} \mathrm{W}$.

successfully simulates the observed spatial distribution of the monthly monsoonal evolution with the northward migration of the rain-belt. The model reproduces the monsoonal precipitation maximum across northwest Mexico.

It has been stated that the NA monsoon is most visible in Arizona and New Mexico states of the US and the northwest of Mexico (Adams and Comire, 1997). Four subregions (black boxes) are further defined for time series analysis within the NAM region: DESERT, CORE, AZNM, and TXNM (Fig. 6). The DESERT region is defined to cover the dust source region with a very low precipitation $\left(<10 \mathrm{~mm} \mathrm{month}^{-1}\right)$. The CORE region is defined to cover the tongue of the NAM rain-belt that receives the highest precipitation among the four sub-regions. The AZNM region is defined as the region over Arizona and New Mexico, which are the two states that are most affected by the NAM in the southwestern US and receive $\sim 50 \%$ of their annual precipitation during the NAM season (Adams and Comrie, 1997). The TXNM region is defined adjacent to the east of the CORE and AZNM regions.

The NAM circulation is driven by pressure gradient induced by the thermal contrast between land and ocean. Figure 7 shows the monthly mean spatial distribution of sea level pressure (SLP) anomalies and integrated moisture fluxes from the WRF-Chem simulations over the NAM region. The SLP anomalies are calculated by subtracting the domainaveraged value from the SLP at each grid. The Sonoran lowpressure center due to surface heating over the desert is well simulated by the model. The simulation also captures the moisture transport from the Gulf of California towards Arizona (AZ) particularly during July and August. During the two summer months, our simulation showed that moisture transport from the Gulf of California originates from southeasterly flow from the Gulf of Mexico that crosses over the SMO before turning more southerly over the Gulf of California and directing moisture to AZ. This suggests that the Gulf of Mexico and the land east of the SMO also provide impor- tant moisture sources for the NAM precipitation (Adam and Comrie 1997). The importance of the east-to-west cross barrier moisture flux over the SMO has been noted by Higgins et al. (2004) and Schiffer and Nesbitt (2012).

The lower tropospheric moisture transports over the NAM region are also demonstrated as longitude-height crosssection of zonal and meridional moisture fluxes. Figure 8 shows the WRF-Chem simulated monthly mean crosssection of zonal circulation and meridional moisture fluxes at $29^{\circ} \mathrm{N}$ from $115^{\circ} \mathrm{W}$ to $105^{\circ} \mathrm{W}$ (Fig. 7) during the NAM season, extending across the Gulf of California onto the high topography of the SMO. At $29^{\circ} \mathrm{N}$, the Gulf of California extends zonally between $113^{\circ} \mathrm{W}$ and $111^{\circ} \mathrm{W}$. The model correctly resolves the low level southerly jet along the western foothills of the SMO, extending from surface to $900 \mathrm{hPa}$. The model clearly exhibits a monthly-mean southerly moisture fluxes maximum near $111^{\circ} \mathrm{W}$ in the vicinity of Gulf of California. The low-level southerly moisture fluxes increase from $10 \mathrm{~g} \mathrm{~kg}^{-1} \mathrm{~m} \mathrm{~s}^{-1}$ to $50 \mathrm{~g} \mathrm{~kg}^{-1} \mathrm{~m} \mathrm{~s}^{-1}$ from June to August. On the other side, the eastern slopes of the SMO, the model also simulates the near-surface southerly moisture fluxes from the Gulf of Mexico. Corresponding to the two southerly jets confined to the lower atmosphere, the model also simulates a northerly moist jet at $700-800 \mathrm{hPa}$ at $\sim 109^{\circ} \mathrm{W}$ near the top of the SMO. Besides the meridional jets, the zonal moisture fluxes show a convergence at the western slope of the SMO, which is consistent with the maximum NAM precipitation over the region. The convergence is stronger in July-August than June.

\subsubsection{Dust impact on precipitation and circulation}

Figure 9 shows spatial distributions of monthly mean dustinduced change of precipitation from the WRF-Chem simulations in June, July, and August averaged for 1995-2009 over the NAM region. The dust-induced precipitation change is calculated by subtracting the results from the WRF-Chem 


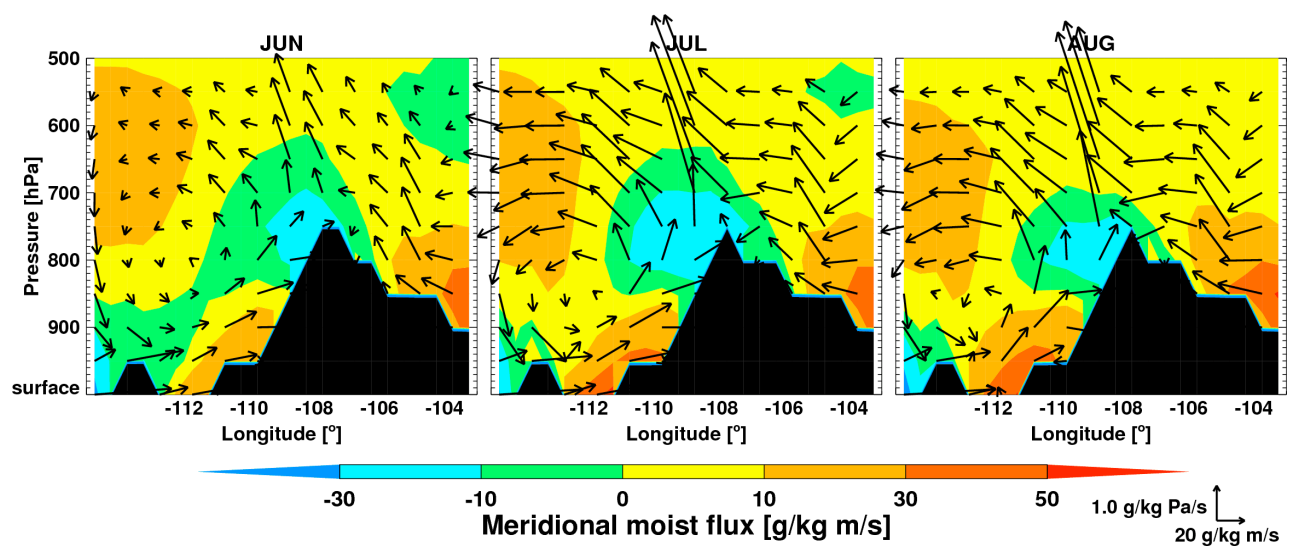

Fig. 8. Monthly mean cross sections of zonal circulation and meridional moisture fluxes at $29^{\circ} \mathrm{N}$ from $115^{\circ} \mathrm{W}$ to $105^{\circ} \mathrm{W}$ (Fig. 7 ) during the NAM season. The color contour shows the meridional moisture fluxes. The positive values represent southerlies and negative values represent northerlies.

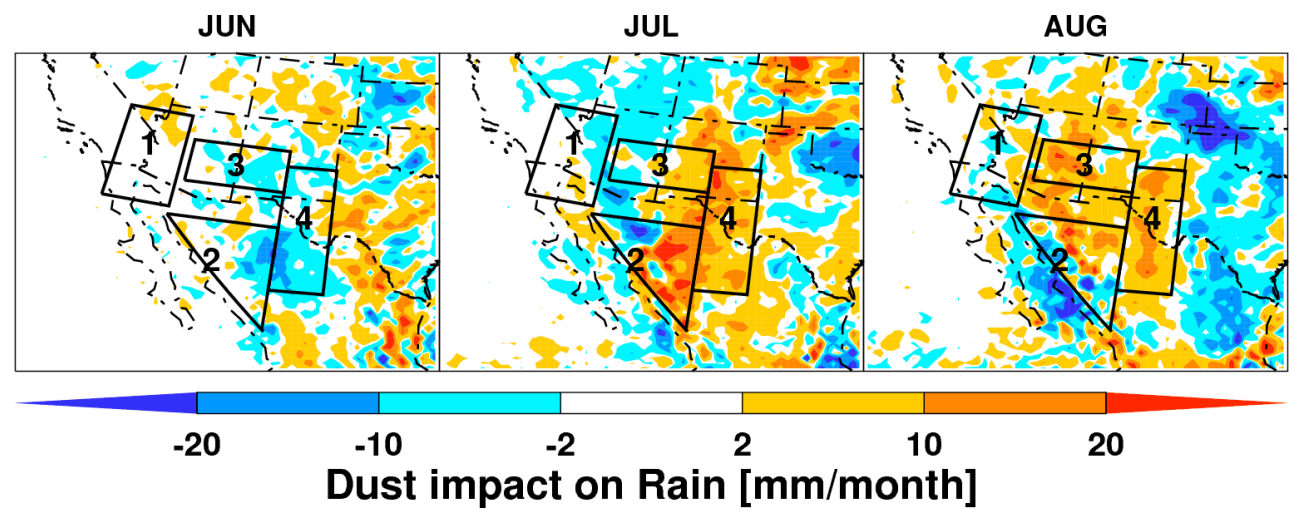

Fig. 9. Spatial distributions of monthly mean dust-induced change of precipitation from the WRF-Chem simulations in June, July, and August averaged for 1995-2009 over the NAM region. Four sub-regions are defined in the black boxes: Region 1 (DESERT), Region 2 (CORE), Region 3 (AZNM), and Region 4 (TXNM).

simulations without dust from the results from the WRFChem simulations with dust. Although the dust-induced precipitation change occurs over all the three sub-regions (CORE, AZNM, and TXNM) for July and August, the statistically significant impact of dust is mainly found within the AZNM and TXNM regions. The dust-induced precipitation change over these two regions exceeds the $90 \%$ statistical significance level based on the Student's t-test. The dustinduced precipitation over the CORE region is not statistical significant.

Figure 10 shows the monthly precipitation and dustinduced change over the three NAM sub-regions (CORE, AZNM, and TXNM) from WRF-Chem simulations during May-August averaged for 1995-2009. In general, the WRF-Chem simulations without dust show that precipitation increases from $\sim 40 \mathrm{~mm} \mathrm{month}^{-1}$ to $\sim 200 \mathrm{~mm} \mathrm{month}^{-1}$ over the CORE region and from $\sim 24 \mathrm{~mm} \mathrm{month}^{-1}$ to $\sim 65 \mathrm{~mm} \mathrm{month}^{-1}$ over the AZNM region during MayAugust corresponding to the NAM northward migration, while the precipitation over the TXNM region reduces from $\sim 56 \mathrm{~mm} \mathrm{month}^{-1}$ to $\sim 40 \mathrm{~mm} \mathrm{month}^{-1}$. Over the CORE region, dust increases precipitation by $3 \mathrm{~mm} \mathrm{month}^{-1}(1 \%)$ in July and $12 \mathrm{~mm} \mathrm{month}^{-1}(6 \%)$ in August. Over the AZNM region, dust increases precipitation by $6 \mathrm{~mm} \mathrm{month}^{-1}(12 \%)$ in July and $3 \mathrm{~mm}$ month $^{-1}(6 \%)$ in August. Over the TXNM region, dust increases precipitation by $12 \mathrm{~mm} \mathrm{month}^{-1}$ $(25 \%)$ in July and $15 \mathrm{~mm} \mathrm{month}^{-1}(40 \%)$ in August. Although the monthly variation of precipitation over the TXNM region corresponds least with the NAM migration, the dustinduced precipitation change increases most significantly along with the NAM migration. The dust-induced change of diurnal cycle of NAM precipitation over the three regions is also investigated. There is no significant dust-induced change of diurnal amplitude and phase of NAM precipitation (not shown), which is related to the low dust concentration and therefore negligible impact on atmospheric stability over the precipitation region. 

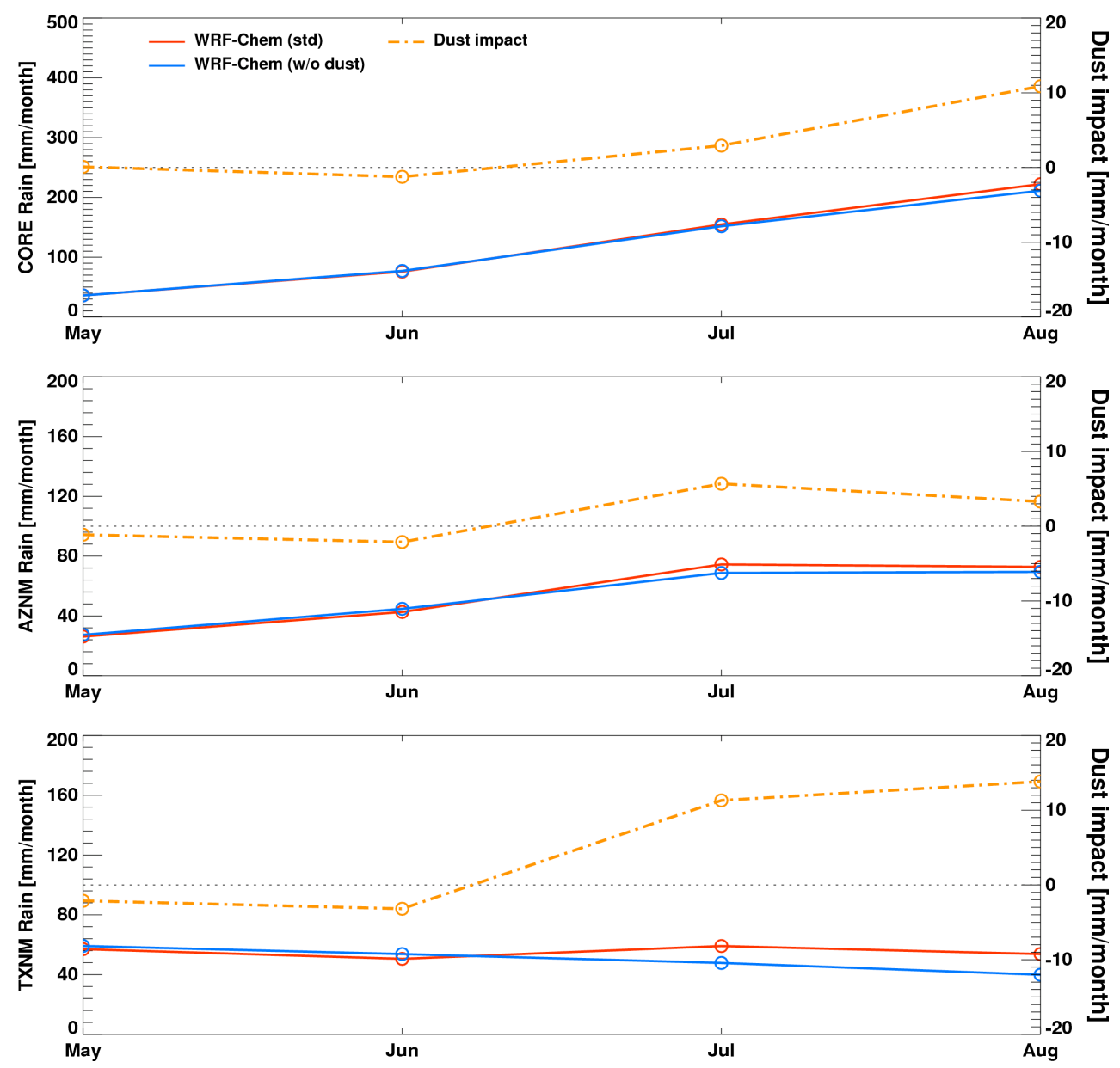

Fig. 10. Monthly precipitation and dust-induced change averaged over the three NAM sub-regions (CORE, AZNM, and TXNM) from the WRF-Chem simulations for May-August, 1995-2009.

Dust affects precipitation mainly through changes in the surface energy budget and atmospheric diabatic heating profiles via direct radiative forcing and changes in cloud property via semi-direct and indirect radiative forcing. Locally, dust aerosol cools the surface and warms the atmosphere during daytime, hence increases atmospheric stability (e.g., Zhao et al., 2011). However, over the NAM region, since most of the dust concentrates over the DESERT region, the dust direct and semi-direct radiative forcing over the three sub-regions (CORE, AZNM, and TXNM) is relatively small (Fig. 5). Although the model simulates the dust CCN effect on stratiform (large-scale) clouds, there is no treatment of dust as ice nuclei (IN). In addition, dust indirect effects on convective cloud and precipitation are not represented in the current convective microphysical parameterization, while convective clouds generate over $90 \%$ of precipitation during the NAM season in the simulations. Therefore, dust indirect effect is also limited over the three sub-regions in our simulations. However, the heated air by dust over the DESERT region could remotely affect the overall monsoonal circulations (e.g., Lau et al., 2006 and 2009).

Figure 11 shows the spatial distributions of monthly mean dust-induced change of SLP and integrated moisture fluxes from the WRF-Chem simulations in June, July, and August averaged for 1995-2009 over the NAM region. Over the deserts, dust leads to a small surface cooling due to reduction of radiation (Fig. 5). The surface cooling is too small to induce changes in SLP during July, but the increase in SLP is more notable in August. The diabatic heating resulted from dust leads to an anomalous cyclonic circulation centering over the desert region, which transport more moist air from the Pacific Ocean and Gulf of California towards the SMO and increases the precipitation in northwestern Mexico. This anomalous westerly to southwesterly moisture flux counters the cross barrier moisture flux over the SMO shown in Fig. 7, leading to moisture flux convergence and enhanced precipitation. The anomalous cyclonic circulation also enhances cloud and precipitation in the AZNM and TXNM regions in July. The reduced SLP over AZNM and TXNM 


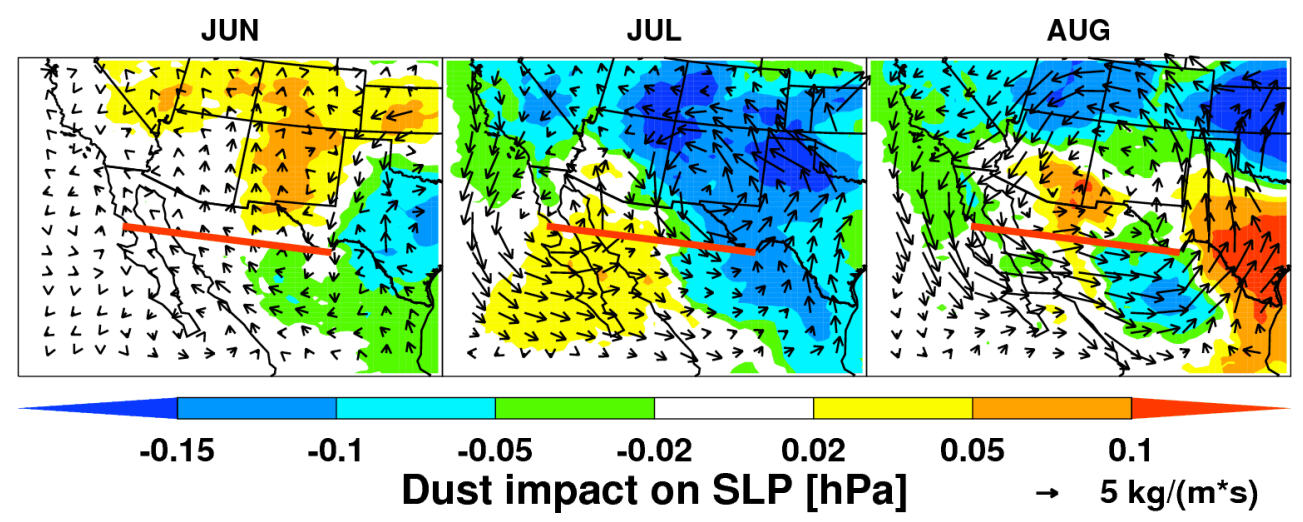

Fig. 11. Spatial distributions of monthly mean dust-induced change of sea level pressure (SLP) and integrated moisture fluxes from the WRF-Chem simulations in June, July, and August averaged for 1995-2009 over the NAM region. The red line represents the cross section at $29^{\circ} \mathrm{N}$ from $115^{\circ} \mathrm{W}$ to $105^{\circ} \mathrm{W}$.

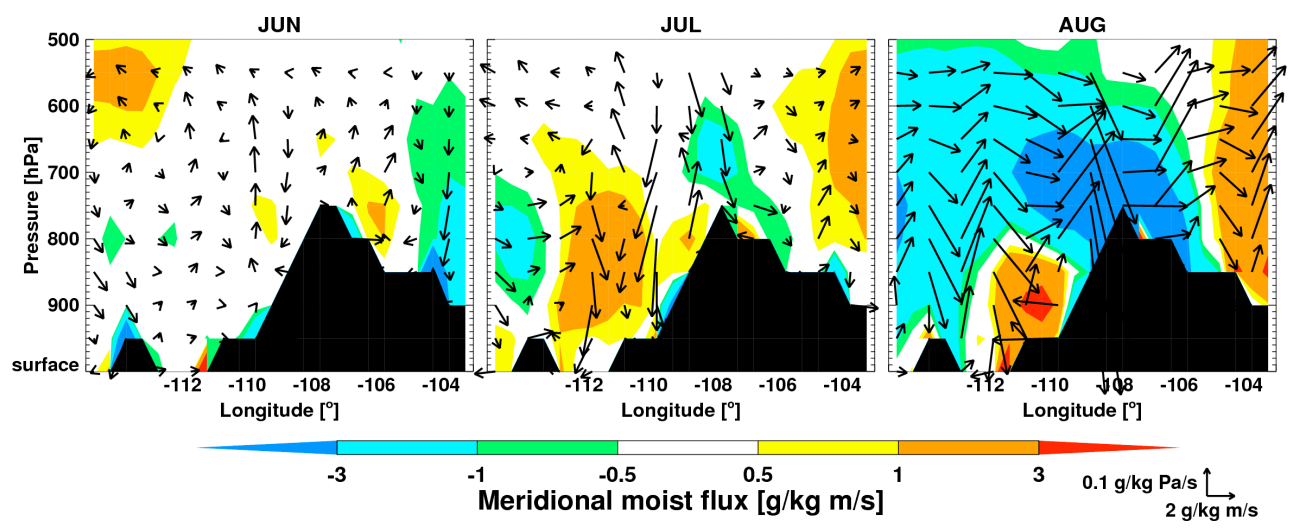

Fig. 12. Monthly mean cross sections of dust-induced change of zonal and meridional moisture fluxes at $29^{\circ} \mathrm{N}$ from $115^{\circ} \mathrm{W}$ to $105^{\circ} \mathrm{W}$ during the NAM season. The color contour shows the change in meridional moisture fluxes. The positive values represent increase in southerlies and negative values represent increase in northerlies.

generates a larger anomalous cyclonic circulation in August that continues to bring in moist air to the SMO and TXNM regions.

Figure 12 shows the monthly mean cross sections of dustinduced change of zonal and meridional moisture fluxes at $29^{\circ} \mathrm{N}$ from $115^{\circ} \mathrm{W}$ to $105^{\circ} \mathrm{W}$ during the NAM season averaged for 1995-2009. Same as shown in Fig. 11, in general, the dust impact on the moisture transport is negligible in June, but it becomes significant in July and August. In July and August, the southerly moisture fluxes are strengthened by $1-6 \mathrm{~g} \mathrm{~kg}^{-1} \mathrm{~m} \mathrm{~s}^{-1}(\sim 10 \%)$ on both western and eastern slopes of the SMO. In the meantime, the easterly moisture fluxes are also strengthened by the dust-induced heating, particularly in August, resulting in a shift of moisture convergence to the east of the SMO. Overall, the dust helps to draw in warm and moist air from the Gulfs of California and Mexico, resulting in a general increase in NAM precipitation over all three sub-regions.

The TXNM region is taken as an example to further illustrate the correlation between dust-induced diabatic heat- ing and the NAM precipitation change. Figure 13 shows the monthly daytime dust-induced diabatic heating change over the DESERT region along with the dust-induced precipitation change over the TXNM region for May-August, 1995-2009 from the WRF-Chem simulations. In May, dustinduced atmospheric diabatic heating over the DESERT region is small. It increases significantly from $0.05 \mathrm{~K} \mathrm{day}^{-1}$ to $0.5 \mathrm{~K} \mathrm{day}^{-1}$ from May to July-August. The dust heating effect reaches a maximum in July. Corresponding to the dust heating in the lower atmosphere (below $800 \mathrm{hPa}$ ), the dustinduced precipitation change over the TXNM region gradually increases from June to July when dust heating in the lower atmosphere over the DESERT region is largest.

\section{Summary and conclusions}

In this study, the radiative forcing of dust from the Southwest US deserts and its feedback to the monsoon precipitation and circulation over the NAM region are investigated 


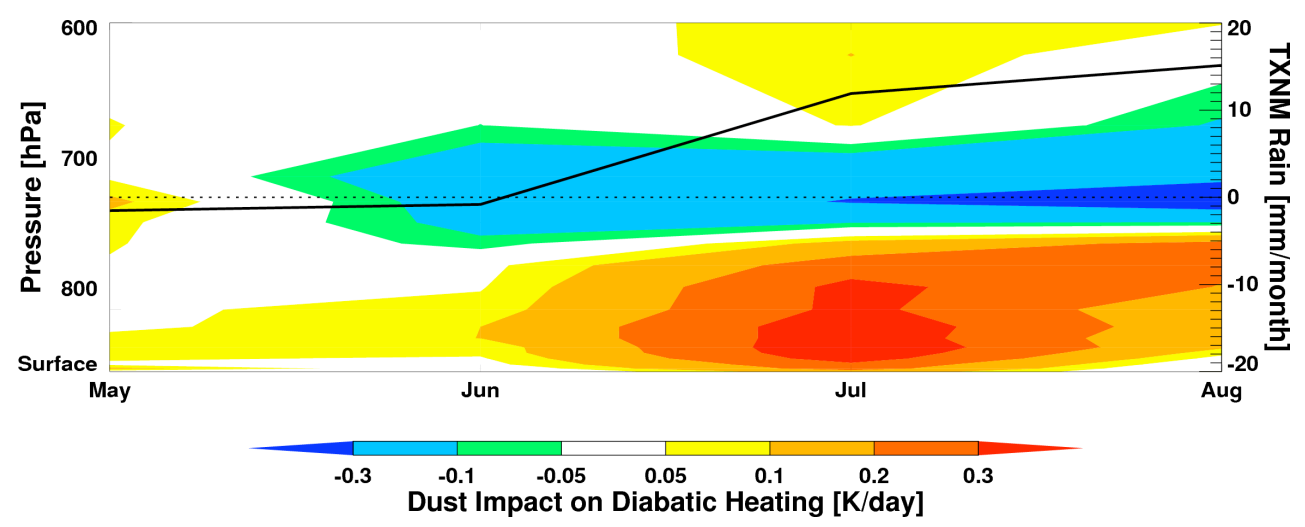

Fig. 13. Monthly dust-induced daytime diabatic heating change over the DESERT region along with the dust-induced precipitation change over the TXNM region from the WRF-Chem simulations for May-August 1995-2009.

using the WRF-Chem model. To establish statistical significance of dust effects, simulation results for June-August of 1995-2009 are analyzed to capture potential dominant dust effects above interannual variability. Both dust SW and LW direct radiative effect are included. Generally, the model simulates reasonable aerosol mass concentrations and optical depth over the NAM region during summer. Compared to the observations, the model successfully reproduces the magnitude and spatial distribution of NAM precipitation.

The WRF-Chem simulates a total dust emission of $2.4 \mathrm{Tg}$ during the NAM season. The dust concentrates near the source region in the lower atmosphere (below $800 \mathrm{hPa}$ ) during summer, resulting in negative TOA forcing by up to $-1.25 \mathrm{~W} \mathrm{~m}^{-2}$ over the source region. In the atmosphere, the dust absorbs SW and warms the atmosphere by $0.05 \mathrm{~W} \mathrm{~m}^{-2}$ on domain average and up to $0.6 \mathrm{~W} \mathrm{~m}^{-2}$ over the source region. At the surface, the dust has a cooling effect of $-0.15 \mathrm{~W} \mathrm{~m}^{-2}$ on domain average and $-1.38 \mathrm{~W} \mathrm{~m}^{-2}$ on maximum over the source region. Overall, the net $(\mathrm{LW}+\mathrm{SW})$ radiative effect of dust is atmospheric warming, surface cooling, and negative TOA forcing over North America.

The WRF-Chem successfully simulates the observed spatial distribution of the monthly monsoonal evolution with the northward migration of the rain-belt and properly resolves the low level southerly jet along the western foothills of the SMO, extending from the surface to $900 \mathrm{hPa}$. The dust affects the NAM precipitation mostly over three NAM sub-regions: CORE, AZNM, and TXNM in July and August. Dust increases precipitation by $3 \mathrm{~mm} \mathrm{month}^{-1}$ (1\%), $6 \mathrm{~mm} \mathrm{month}^{-1}(12 \%)$, and $12 \mathrm{~mm} \mathrm{month}^{-1}(25 \%)$ in July and $12 \mathrm{~mm} \mathrm{month}^{-1}(6 \%), 3 \mathrm{~mm} \mathrm{month}^{-1}(6 \%)$, and $15 \mathrm{~mm} \mathrm{month}^{-1}$ (40\%) in August over the CORE, AZNM, and TXNM regions, respectively. The dust-induced precipitation change over the AZNM and TXNM regions exceeds the $90 \%$ statistical significance level based on the Student's t-test.

The dust-induced precipitation change is facilitated by the dust-heated air over the DESERT region that helps to draw warm and moist air from the Gulfs of California and Mexico. In July and August, the dust-induced atmospheric diabatic heating leads to an anomalous cyclonic circulation centering over the desert region. This anomalous southwesterly moisture flux strengthened the southerly monsoonal moisture fluxes at lower atmosphere by $\sim 10 \%$ on both western and eastern slopes of the SMO. In the meantime, the anomalous westerly moisture flux counters the cross barrier monsoonal moisture flux, resulting in an eastward shift of moisture convergence, leading to the largest precipitation increase in the TXNM region. The dust-induced precipitation changes are highly correlated with the dust-induced lower atmospheric (below $800 \mathrm{hPa}$ ) diabatic heating (up to $0.5 \mathrm{~K} \mathrm{day}^{-1}$ in July and August) over the DESERT region. This mechanism of remote impact of dust on the overall monsoonal circulations is similar as that proposed by Lau et al. (2006 and 2009) over Asia and West Africa.

Compared to the previous studies on the Saharan dust impact on the West Africa Monsoon (WAM) system (e.g., Lau et al. 2009), the dust from the Southwest US deserts plays a similar role as a "heat pump" to strengthen the monsoon circulation and re-distributes the precipitation. Although the dust forcing over the southwestern US is much smaller than the Saharan dust over West Africa, it still has a significant impact on the NAM circulation and precipitation, because the diabatic heating that drives the NAM is also much smaller than that of WAM. For example, residual diagnosis of NAM diabatic heating based on two global reanalysis data suggests a maximum averaged low level heating no more than $1.5 \mathrm{~K} \mathrm{day}^{-1}$ in the SMO (Barlow et al. 1998) $\left(1-2 \mathrm{~K} \mathrm{day}^{-1}\right.$ at $700 \mathrm{hPa}$ simulated in this study). Therefore the dust heating of $0.5 \mathrm{~K} \mathrm{day}^{-1}$ estimated from our simulations could produce significant effects on the NAM circulation depending on its location and vertical distribution. However, the diurnal cycle of NAM precipitation is not changed significantly by the Southwest US dust, which is different from the role of Saharan dust found by previous studies (e.g., Kim et al., 2010; Zhao et al., 2011). The negligible dust impact on the diurnal 
cycle of NAM precipitation is related to the low dust concentration and therefore negligible impact on atmospheric stability over the precipitation region. Overall, this study highlights the interaction between the Southwest US dust and NAM system and motivates further investigation of possible dust feedback on the monsoon under climate change and the projected mega-drought conditions over the southwestern US in the 21 st century.

Finally, several caveats should be noted in this study. First, in the absence of measurements of optical properties of dust from the Southwest US deserts, this study uses the same refractive index of dust as our previous studies over West Africa (Zhao et al., 2010 and 2011). The imaginary part of dust refractive index is uncertain (e.g., Balkanski et al., 2007; McConnell et al., 2010; Zhao et al., 2011) and may change the dust-induced atmospheric diabatic heating, which triggers the NAM circulation and precipitation change. In order to constrain the dust absorption, measurements of the optical properties of the Southwest US dust are required in the future. Second, although the dust impact on diabatic heating and hence the NAM circulation is evident, the dust-induced changes of NAM precipitation may be sensitive to the cloud microphysics and convective schemes used in the model, which is beyond the scope of this study. We note, however, that the simulations reported in this study reproduced the seasonal cycle and spatial distribution of NAM precipitation rather well, hence lending some confidence in simulated response to changes in dust diabatic heating. Third, although the dust-induced atmospheric heating influences the NAM circulation and precipitation, the effect cannot be fully simulated using a regional modeling framework because the same SST lower boundary conditions and atmospheric lateral boundary conditions are used in the simulations with and without dust. However, this limitation may not have large impacts because the dust is rather spatially confined so its impacts on large-scale circulation may not extend well beyond the boundaries of our simulation domain. On the other hand, NAM precipitation is generally not well simulated by GCM's because higher spatial resolution is needed to represent the complex landscape and its interactions with regional and large-scale circulation over the NAM region. Last, dust indirect effects on convective clouds and precipitation are not represented in the current convective parameterization, but convective precipitation dominates the total precipitation during the NAM season (generating over $90 \%$ of precipitation in the simulations). In addition, the dust aerosol cannot be activated as ice nuclei (IN) to influence clouds in the Morrison microphysics scheme in this study. Despite the low occurrence of dust over the NAM cloud/precipitation region, episodic intrusions of dust to the CORE region due to anomalous transport could result in aerosol indirect effects that deserve further study in the future.
Acknowledgements. This study is supported by the Department of Energy Earth System Modeling Program Investigations on the Magnitude and Probabilities of Abrupt Climate TransitionS (IMPACTS) project. This research used computing resources from the National Energy Research Scientific Computing Center, which is supported by the Office of Science of the US Department of Energy under Contract No. DE-AC02-05CH11231. Pacific Northwest National Laboratory is operated for the US DOE by Battelle Memorial Institute under contract DE-AC06-76RLO330 1830. We thank Nicole Riemer for the editorial help. Insightful comments offered by Stephen Nesbitt and the other anonymous referee are highly appreciated.

Edited by: N. Riemer

\section{References}

Ackermann, I. J., Hass, H., Memmesheimer, M., Ebel, A., Binkowski, F. S., and Shankar, U.: Modal aerosol dynamics model for Europe: Development and first applications, Atmos. Environ., 32, 2981-2999, 1998.

Adams, D. and A. C. Comrie: The North American Monsoon, B. Am. Meteorol. Soc., 78, 2197-2213, 1997.

Balkanski, Y., Schulz, M., Claquin, T., and Guibert, S.: Reevaluation of Mineral aerosol radiative forcings suggests a better agreement with satellite and AERONET data, Atmos. Chem. Phys., 7, 81-95, doi:10.5194/acp-7-81-2007, 2007.

Barlow, M., Nigam, S., and Berbery, E. H.: Evolution of the North American Monsoon System, J. Clim., 11, 2238-2257, 1998.

Barnard, J. C., Fast, J. D., Paredes-Miranda, G., Arnott, W. P., and Laskin, A.: Technical Note: Evaluation of the WRF-Chem "Aerosol Chemical to Aerosol Optical Properties" Module using data from the MILAGRO campaign, Atmos. Chem. Phys., 10, 7325-7340, doi:10.5194/acp-10-7325-2010, 2010.

Diner, D. J., Beckert, J., Reilly, T., Bruegge, C., Conel, J., Kahn, R., Martonchik, J., Ackerman, T., Davies, R., Gerstl, S., Gordon, H., Muller, J., Myneni, R., Sellers, P.J., Pinty, B., and Verstraete, M.: Multi-angle Imaging SpectroRadiometer (MISR) instrument description and experiment overview, IEEE T., Geosci. Remote, 36, 1072-1087, 1998.

Diner, D. J., Abdou, W. A., Bruegge, C. J., Conel, J. E., Crean, K. A., Gaitley, B. J., Helmlinger, M. C., Kahn, R. A., Martonchik, J. V., and Pilorz, S. H.: MISR aerosol optical depth retrievals over southern Africa during the SAFARI-2000 dry season campaign, Geophys. Res. Lett., 28, 3127-3130, 2001.

Dubovik, O. and King, M. D.: A flexible inversion algorithm for retrieval of aerosol optical properties from sun and sky radiance measurements, J. Geophys. Res., 105, 20673-20696, 2000.

Dubovik, O., Holben, B., Eck, T. F., Smirnov, A., Kaufman, Y. J., King, M. D., Tanré, D., and Slutsker, I.: Variability of absorption and optical properties of key aerosol types observed in worldwide locations, J. Atmos. Sci., 59, 590-608, 2002.

Fast, J. D, Gustafson Jr., W. I., Easter, R. C., Zaveri, R. A., Barnard, J. C., Chapman, E. G., and. Grell, G. A.: Evolution of ozone, particulates, and aerosol direct forcing in an urban area using a new fully-coupled meteorology, chemistry, and aerosol model, J. Geophys. Res., 111, D21305, doi:10.1029/2005JD006721, 2006.

Fast, J., Aiken, A. C., Allan, J., Alexander, L., Campos, T., Canagaratna, M. R., Chapman, E., DeCarlo, P. F., de Foy, B., Gaffney, 
J., de Gouw, J., Doran, J. C., Emmons, L., Hodzic, A., Herndon, S. C., Huey, G., Jayne, J. T., Jimenez, J. L., Kleinman, L., Kuster, W., Marley, N., Russell, L., Ochoa, C., Onasch, T. B., Pekour, M., Song, C., Ulbrich, I. M., Warneke, C., WelshBon, D., Wiedinmyer, C., Worsnop, D. R., Yu, X.-Y., and Zaveri, R.: Evaluating simulated primary anthropogenic and biomass burning organic aerosols during MILAGRO: implications for assessing treatments of secondary organic aerosols, Atmos. Chem. Phys., 9, 6191-6215, doi:10.5194/acp-9-6191-2009, 2009.

Ghan, S., Laulainen, N., Easter, R., Wagener, R., Nemesure, S., Chapman, E., Zhang, Y., and Leung, R.: Evaluation of aerosol direct radiative forcing in MIRAGE, J. Geophys. Res., 106, 52955316, 2001.

Ginoux, P., Chin, M., Tegen, I., Prospero, J. M., Holben, B., Dubovik, O., and Lin, S.: Sources and distributions of dust aerosols simulated with the GOCART model, J. Geophys. Res., 106, 20225-20273, 2001.

Gochis, D. J., Nesbitt, S., Yu, W., and Williams, S. F.: Assessment of quantitative precipitation estimates from space-borne platforms during the 2004 North American Monsoon Experiment, Atmosfera, 22, 69-98, 2009

Grell, G. A., Peckham, S. E., Schmitz, R., McKeen, S. A., Frost, G., Skamarock, W. C., and Eder, B.: Fully coupled "online" chemistry within the WRF model, Atmos. Environ., 39, 6957-6976, 2005.

Gustafson, W. I., Chapman, E. G., Ghan, S. J., Easter, R. C., and Fast, J. D.: Impact on modeled cloud characteristics due to simplified treatment of uniform cloud condensation nuclei during NEAQS 2004, Geophys. Res. Lett., 34, L19809, doi:10.1029/2007GL030021, 2007.

Gutzler, D. S. and Coauthors: North American monsoon Model Assessment Project (NAMAP). NCEP/Climate Prediction Center Atlas No. 11, 32 pp., available at http://www.cpc.ncep.noaa. gov/research_papers/ncep_cpc_atlas/11/atlas11.htm, 2004.

Gutzler, D. S., L. N. Long, J. Schemm, S. Baidya Roy, M. Bosilovich, Collier, J. C., Kanamitsu, M., Kelly, P., Lawrence, D., Lee, M., Sanchez, R., Mapes, B., Mo, K., Nunes, A., Ritchie, E., Roads, J., Schubert, S., Wei, H., and Zhang, G.: Simulations of the 2004 North American Monsoon: NAMAP2. J. Climate, 22, 6716-6740, doi:10.1175/2009JCLI3138.1, 2009.

Holben, B. N., Eck, T. F., Slutsker, I., Tanr' e, D., Buis, J. P., Stezer, A., Vermote, E., Reagan, Y., Kaufman, U. J., Nakajima, T., Lavenu, F., Jankowiak, I., and Smirnov, A.: AERONET-A federated instrument network and data archive for aerosol characterization, Remote Sens. Environ., 66, 1-16, 1998.

Holben, B. N., Tanré, D., Smirnov, A., ECK T. F., Slutsker, I., Abuhassan, N., Newcomb, W., Schafer, J., Chatenet, B., Lavenu, F., Kaufman, Y., Vande Castle, J., Setzer, A., Markham, B., Clark, D., Frouin, R., Halthore, R., Karneli, A., O’Neill, N., Pietras, C., Pinker, R., Voss, K., and Zibordi, G.: An emerging ground-based aerosol climatology: Aerosol optical depth from AERONET, J. Geophys. Res., 106, 12067-12097, 2001.

Hsu, K., Gao, X., Sorooshian, S., and Gupta, H. V.: Precipitation estimation from remotely sensed information using artificial neural networks, J. Appl. Meteor., 36, 1176-1190, 1997.

Hsu, K., Gupta, H., Gao, X., and Sorooshian, S.: Estimation of physical variables from multi-channel remotely sensed imagery using a neural network: application to rainfall estimation, Water Resour. Res., 35, 1605-1618, 1999.
Hsu, N. C., Tsay, S., King, M., and Herman, J. R.: Deep blue retrievals of Asian Aerosol Properties during ACE-Asia, IEEE Trans. Geosci. Remote Sens., 44, 3180, doi:10.1109/TGRS.2006.879540, 2006.

Huffman, G. J., Adler, R. F., Morrissey, M., Bolvin, D. T., Curtis, S., Joyce, R., McGavock, B., and Susskind, J.: Global Precipitation at One-Degree Daily Resolution from Multi-Satellite Observations, J. Hydrometeor., 2, 36-50, 2001.

Huffman, G. J., Adler, R. F., Bolvin, D. T., Gu, G., Nelkin, E. J., Bowman, K. P., Hong, Y., Stocker, E. F., and Wolff, D. B.: The TRMM Multi-satellite Precipitation Analysis: QuasiGlobal, Multi-Year, Combined-Sensor Precipitation Estimates at Fine Scale. J. Hydrometeor., 8, 38-55, 2007.

Iacono, M. J., Mlawer, E. J., Clough, S. A., and Morcrette, J.-J.: Impact of an improved longwave radiation model, RRTM. on the energy budget and thermodynamic properties of the NCAR community climate mode, CCM3, J. Geophys. Res., 105, 1487314890, 2000.

Kaufman, Y. J., Tanré, D., Remer, L. A., Vermote, E. F., Chu, A., and Holben, B. N.: Operational remote sensing of tropospheric aerosol over land from EOS moderate resolution imaging spectroradiometer, J. Geophys. Res., 102, 17051-17067, 1997.

Kim, K.-M., Lau, W. K.-M., Sud, Y. C., and Walker, G. K.: Influence of aerosol-radiative forcings on the diurnal and seasonal cycles of rainfall over West Africa and Eastern Atlantic Ocean using GCM simulations, Clim. Dynam., 35, 115-126, doi:10.1007/s00382-010-0750-1, 2010.

Lau, K. M., Kim, K. M., Sud, Y. C., and Walker, G. K.: A GCM study of the response of the atmospheric water cycle of West Africa and the Atlantic to Saharan dust radiative forcing, Ann. Geophys., 27, 4023-4037, doi:10.5194/angeo-27-40232009, 2009.

Levy, R. C., Remer, L. A., Tanré, D., Kaufman, Y. J., Ichoku, C., Holben, B. N., Livingston, J. M., Russell, P. B., and Maring, H.: Evaluation of the Moderate-Resolution Imaging Spectroradiometer (MODIS) retrievals of dust aerosol over the ocean during PRIDE, J. Geophys. Res., 108, D198594, doi:10.1029/2002JD002460, 2003.

Malm, W., Sisler, J., Huffman, D., Eldred, R., and Cahill, T.: Spatial and seasonal trends in particle concentration and optical extinction in the United States, J. Geophys. Res., 99, 1347-1370, 1994.

Martonchik, J. V., Diner, D. J., Kahn, R., and Gaitley, B.: Comparison of MISR and AERONET aerosol optical depths over desert sites, Geophys. Res. Lett., 31, L16102, doi:10.1029/2004GL019807, 2004.

McConnell, C. L., Formenti, P., Highwood, E. J., and Harrison, M. A. J.: Using aircraft measurements to determine the refractive index of Saharan dust during the DODO Experiments, Atmos. Chem. Phys., 10, 3081-3098, doi:10.5194/acp-10-3081-2010, 2010.

McKeen, S. A., Wotawa, G., Parrish, D. D., Holloway, J. S., Buhr, M. P., Hubler, G., Fehsenfeld, F. C., and Meagher, J. F.: Ozone production from Canadian wildfires during June and July of 1995, J. Geophys. Res., 107, 4192, doi:10.1029/2001JD000697, 2002.

Miller, R. L., Tegen, I., and Perlwitz, J.: Surface radiative forcing by soil dust aerosols and the hydrologic cycle, J. Geophys. Res., 109, D04203, doi:10.1029/2003JD004085, 2004. 
Mlawer, E. J., Taubman, S. J., Brown, P. D., Iacono, M. J., and Clough, S. A.: RRTM, a validated correlated-k model for the longwave, J. Geophys. Res., 102, 16663-16682, 1997.

Mo, K. C. and Berbery, E. H.: Low-level jets and the summer precipitation regimes over North America. J. Geophys. Res., 109, D06117, doi:10.1029/2003JD004106, 2004.

Nesbitt, S. W., Gochis, D. J., and Lang, T. J.: The Diurnal Cycle of Clouds and Precipitation along the Sierra Madre Occidental Observed during NAME-2004: Implications for Warm Season Precipitation Estimation in Complex Terrain. J. Hydrometeor., 9, 728-743, 2008.

Remer, L. A., Kaufman, Y. J., Tanré, D., Mattoo, S., Chu, D. A., Martins, J. V., Li, R., Ichoku, C., Levy, R. C., Kleidman, R. G., Eck, T. F., Vermote, E., and Holben, B. N.: The MODIS aerosol algorithm, products and validation. J. Atmos. Sci., 62, 947-973, 2005.

Schell, B., Ackermann, I. J., Hass, H., Binkowski, F. S., and Ebel, A.: Modeling the formation of secondary organic aerosol within a comprehensive air quality modeling system, J. Geophys. Res., 106, 28275-28293, 2001.

Schiffer, N. and Nesbitt, S.: Flow, moisture, and thermodynamic variability associated with Gulf of California surges within the North American Monsoon, J. Climate, doi:10.1175/JCLI-D-1100266.1, in press, 2012.

Seager, R., Ting, M., Held, I., Kushnir, Y., Lu, J., Vecchi, G., Huang, H., Harnik, N., Leetmaa, A., Lau, N., Li, C., Velez, J., and Naik, N.: Model Projections of an Imminent Transition to a More Arid Climate in Southwestern North America, Science, 316, 1181-1184, doi:10.1126/science.1139601, 2007.

Skamarock, W. C., Klemp, J. B., Dudhia, J., Gill, D. O., Barker, D. M., Duda, M. G., Huang, X., Wang, W., and Powers, J. G.: A description of the advanced research WRF version 3, NCAR Tech. Note, NCAR/TN-475+STR, 8 pp., Natl. Cent. for Atmos. Res., Boulder, CO, USA, available at: http://www.mmm.ucar. edu/wrf/users/docs/arw_v3.pdf, 2008,

Sokolik, I. N., Toon, O. B., and Bergstrom, R. W.: Modelling the radiative characteristics of air-airborne mineral aerosols at infrared wavelengths, J. Geophys. Res., 103, 8813-8826, 1998.
Sorooshian, S., Hsu, K., Gao, X., Gupta, H., Imam, B., and Braithwaite, D.: Evaluation of PERSIANN system satellite-based estimates of tropical rainfall, B. Am. Meteorol. Soc., 81, 2035-2046, 2000.

Stockwell, W. R., Middleton, P., Chang, J. S., and Tang, X.: The second generation regional acid deposition model chemical mechanism for regional air quality modeling, J. Geophys. Res., 95, 16343-16367, 1990.

Van der Werf, G. R., Randerson, J. T., Giglio, L., Collatz, G. J., Mu, M., Kasibhatla, P. S., Morton, D. C., DeFries, R. S., Jin, Y., and van Leeuwen, T. T.: Global fire emissions and the contribution of deforestation, savanna, forest, agricultural, and peat fires (1997-2009). Atmos. Chem. Phys., 10, 11707-11735, 10, http://www.atmos-chem-phys.net/10/11707/10/.5194/acp-1011707-2010, 2010.

Woodhouse, C. A. and Overpeck, J. T.: 2000 Years of Drought Variability in the Central United States, B. Am. Meteo. Soc., 79, 2693-2714, 1998.

Yoshioka, M., Mahowald, N., Conley, A. J., Collins, W. D., Fillmore, D. W., Zender, C. S., and Coleman, D. B.: Impact of desert dust radiative forcing on Sahel precipitation: relative importance of dust compared to sea surface temperature variations, vegetation changes and greenhouse gas warming, J. Climate, 16, 14451467, doi:10.1175/JCLI4056.1, 2007.

Zaveri, R. A. and Peters, L. K.: A new lumped structure photochemical mechanism for large-scale applications, J. Geophys. Res., 104, 30387-30415, 1999.

Zaveri, R. A., Easter, R. C., Fast, J. D., and Peters, L. K.: Model for simulating aerosol interactions and chemistry (MOSAIC), J. Geophys. Res., 113, D13204, doi:10.1029/2007JD008792, 2008.

Zhao, C., Liu, X., Leung, L. R., Johnson, B., McFarlane, S. A., Gustafson Jr., W. I., Fast, J. D., and Easter, R.: The spatial distribution of mineral dust and its shortwave radiative forcing over North Africa: modeling sensitivities to dust emissions and aerosol size treatments, Atmos. Chem. Phys., 10, 8821-8838, doi:10.5194/acp-10-8821-2010, 2010.

Zhao, C., Liu, X., Ruby Leung, L., and Hagos, S.: Radiative impact of mineral dust on monsoon precipitation variability over West Africa, Atmos. Chem. Phys., 11, 1879-1893, doi:10.5194/acp11-1879-2011, 2011. 